\title{
CTSZ wt Allele
}

National Cancer Institute

\section{Source}

National Cancer Institute. CTSZ wt Allele. NCI Thesaurus. Code C49711.

Human CTSZ wild-type allele is located within $20 \mathrm{q} 13$ and is approximately $12 \mathrm{~kb}$ in length.

This allele, which encodes cathepsin Z protein, plays a role in the release of C-terminal amino acids from lysosomal proteins. 